\title{
The Impact of Welfare Law Upon Family Law
}

\author{
Jacobus tenBroek*
}

\section{INTRODUCTION}

$I^{N} T H E$ preparation of a comprehensive social welfare system, welfare planners and legislators might, by a conscious effort and a single bold stroke, cut away from the past and start afresh. In modern times, the one real opportumity to do this occurred in the great depression of the 1930's. In welfare terms, as in most others, the nation was not ready for the depression. There was no existing program which had merely to be expanded and speeded up; no machinery already in existence which only required enlargement and adaptation. True, many of the states had developed rudimentary plans for aged, blind and childrens' aid. Some slight beginnings also had been made on the national level. But these were scattered and largely local improvisations, partial and tentative efforts to meet one or another phase of an overall problem not yet seen in its true magnitude and character. They were wholly inadequate as foundations upon which to build a structure capable of sustaiming the burdens and accommodating the welfare demands of the depression. The role to be played by the nation vis a vis the states, the whole shape and size of the welfare system to be established, the groups to be aided, the type, conditions and amount of assistance to be rendered, the relative roles of legislation and adninistration, the economic and political adjustment and equilibrium of factors and forces -all still basically had to be determined. A new, constructive, and even creative act of statesmanship-redetermiming welfare goals and means, deliberately culling rather than heedlessly accepting past programs for their elements of present value - was thus possible in the depression of the '30's, if it was not inperatively demanded.

If one confines himself to the planning area of the federal Social Security Act, and again narrows that to the public assistance provisions of that measure, it is clear that no such act of imaginative originality took place. The measure turned out to be a miscellaneous admixture of the old and the new in which the old preponderated and the new consisted of adaptations of the already existing. A familiar federal-state, grant-in-aid formula was employed. Rigorously limited minimum standards were set forth in the legislation. Execution was left to a new admimistrative agency. As to sub-

* Professor, University of California at Berkeley; member, State Social Welfare Board. For their painstaking and helpful review of this article in manuscript form the author is imdebted to Elizabeth MacLatchie, Chief, Division of Social Security, and Madeline Sheridan, Acting Chief, Bureau of Old Age Security, of the California State Department of Social Welfare. 
stantive provisions, the Elizabethan poor laws were dusted off and, to some extent, modified, to meet the exigencies of the nation and the moment.

In the creation of a new welfare system, welfare planners and legislators might especially have paused to consider whether traditional legal concepts of property, residence, income, the makeup of the family and the responsibilities of family members-originating in other contexts and properly governing other relationships-were useful and appropriate; or whether, on the other hand, they sliould be completely ignored, entirely new categories being created specifically for welfare purposes.

For example, when questions of support and consumption are at stake, as they are $i \mathrm{~m}$ the welfare program, what is the relevance of accepted distinctions between real and personal property? A home, household goods and personal effects are all equally used and useful as consumption items in everyday living. For welfare purposes, should they all not be lumped together in a single category of personally utilizable property, and a line drawn between them and property which stands im a different relationship to consumption and support, such as rental units, timber land, tractors, stock in trade, and the tools of an artisan? Again, for welfare purposes, why should a house fixed to the realty and used as a home be treated differently from a house trailer which is not fixed to the realty but which is also used as a home? To answer that one is real and the other personal property makes no sense at all. Should real property used as a home and money held to buy real property for use as a home be subjected to different limitations and rules because one is real and the other personal? Is a welfare recipient in any different situation for welfare purposes if: (1) he sells real property and uses therefore a deed of trust and a note; or, (2) he sells the same property, getting the same down payment and monthly payments, but does so by way of a contract of sale? The first of these converts the realty into personalty; the second does not. Is this distinction in the slightest degree material for welfare purposes? For those purposes, is not the material fact that the recipient derives cash in hand and monthly income from the transaction whichever form of conveyance is used?

A similar series of questions might be asked and considerations adduced bearing upon the welfare relevancy of accepted legal notions with respect to residence, income, responsibility of relatives, adoptions and so on.

In the creation of our present welfare system, however, welfare planners and legislators did not pause to reconsider the value and reassess the relevance of accepted legal doctrimes in these areas. On the contrary, they accepted those doctrines lock, stock and barrel. They built the welfare system upon them. They shaped, trimmed and hewed the system to fit around them. The doctrimes lurk in every silent presupposition and every explicit provision. They govern eligibility. They determine the amount of the grant. They are the heart and soul of the means test. 
From these beginnings, however, many changes have been wrought. The basic anomalies and incompatabilities between these legal notions and welfare principles, while not resolved by a sweeping original act, have undergone a continuous process of adjustment. Through a progressive series of modifications, the legal notions have given way to the welfare principles. In various areas and to various degrees, the law of domestic relations has yielded to welfare law. It is the purpose of this article to mark out some of the more important of those areas and degrees, referring primarily to California.

Not only is the impact of the Welfare and Institutions Code upon the Civil Code considerable with respect to the persons to whom the Welfare and Institutions Code applies, but, it is important not to underestimate the numbers of those persons. They constitute a very substantial segment of the population. In California, there are roughly 135,000 children, 12,000 blind and 271,000 old age recipients of public assistance grants. Also directly affected by the welfare law are the families and relatives of these recipients. The jurisdiction of the welfare law thus is not only penetrating but pervasive.

\section{INCOME AND PROPERTY-COMMUNITY AND SEPARATE}

\section{In General}

It is often said by writers on California's community property system that the general theory of the marital relationship is that the husband and wife form a sort of partnership. Property acquired by the labor or skill of either during the marriage belongs to both. But each may possess separate property and engage in separate enterprises. The tendency of statutory amendments to the system has been to enlarge the rights of the wife. Nevertheless, the husband still stands in a superior position at least with respect to nuanagement. Thus, under Civil Code Section 155, the husband and wife "contract towards each other" certain obhigations of mutual respect, fidelity and support; under Civil Code Section 157 "neither .. . has any interest in the property of the other"; under Civil Code Section 158, "either may enter into any engagenient or transaction with the other, or with any other person, respecting property, which either might, if unmarried," modified only by the fact that they stand in a confidential relationship to each other; and under Civil Code Section 161(a), their interests in the community property are "present, existing and equal" though "under the management and control of the husband."

This is not the theory of the nuarital relationship emanating from the Welfare and Institutions Code; nor have the amendments to that code noved in the direction of that theory. In the welfare view, husband and wife are not inerely partners, having contractual obligations towards each other, 
distinct interests in community property and rights to separate property. They are rather regarded as a single, integrated entity, having a single, undivided and unseparated interest in income and property. Both are entitled to draw upon that income and property to meet their needs. Only after these family resources, whether called community or separate, are utilized and have proved insufficient can the State be called upon to intervene and supply aid. This approach pushes into the background, if it does not render entirely irrelevant, questions about the source of the income or property, the mode of its acquisition, its community or separate status, or the relative positions of husband and wife with respect to managenient. Husband and wife are not just upon an equal footing; they are upon the same footing. Distimctions are drawn between earners and non-earners, recipients and non-recipients, eligible and ineligible spouses; but none between husband and wife. While this welfare conception of the marital relationship, inconie and property has not been completely worked out and stated in all of its ramifications in the Welfare and Institutions Code, it is basically present and constitutes the major tendency in that code's development and in the implementing actions taken under it. ${ }^{1}$

It nust be recognized that some support provisions exist in the Civil Code and even in the Penal Code. ${ }^{2}$ Under Civil Code Section 155, the husband and wife are under nutual obligations of support. If the husband fails to discharge this obligation, any good faith supplier to the wife of "articles necessary for her support" can "recover the reasonable value thereof from the husband." 3 Moreover, says Penal Code Section 270(a), "every husband having sufficient ability to provide for his wife's support, or who is able to earn the neans of such wife's support, who willfully abandons and leaves his wife in a destitute condition or who refuses or neglects to provide such wife with necessary food, clothing, shelter or inedical attention, unless by her misconduct he was justified in abandoning her, is punishable by imprisonment ... not exceeding two years, or by fine not exceeding $\$ 1000$, or by both." The obligation of support is reciprocal, though the penal sanctions are confined to the husband. ${ }^{4}$

These provisions are departures from, and contradictions of, the commumity and separate property doctrimes of the Civil Code. But, nore important, for recipients of public welfare, neither the community property nor the support provisions of the Civil Code are controlling. The Welfare

1 The tendencies in welfare law contrary to the conception of the family as an integrated unit are: (1) a policy of stimulating blind recipients to greater efforts in striving to render themselves self-supporting, and of facilitating their doing so by permitting them to retain specified amounts of incone without being conpelled to devote it to immediate consuniption items; (2) the special treatment accorded the aid payment.

2 See 1 Armsstrong, California Farmux Law, c. v, pt. 3 (1953).

3 CAL. Crv. Code $\$ 174$.

${ }^{4}$ CAL. CIV. CoDE $\$ \S 168,171,176$. 
and Institutions Code: (1) to some extent, cuts across the categories and limitations established by these Civil Code provisions, and to that extent modifies or nullifies them; (2) redetermines the character of the interest of husband and wife in community property; (3) resurveys the line between community and separate property; (4) defines and delineates in detail the mutual obligation of support by specifying the circumstances in which earmings, other income, property, real and personal, separate and community, are to be utilized for the maintenance of either or both spouses; (5) shifts the Civil Code emphasis on the rights of third party creditors to collect for necessaries supplied to either of the spouses to emphasis on seeing that those in need receive support and on the availability of income and property therefor; (6) substitutes the judgment of the Legislature and the State Board of Social Welfare for that of the courts as to items and standards of support; and (7) eliminates the distinction between husband and wife manifested by the divergent provisions of the Civil Code.

That when the two are in conflict the Civil Code must give way to the Welfare and Institutions Code for welfare purposes was affirmed by the District Court of Appeal in Kelly v. State Board of Social Welfare.5 The court there said: "There is no denying that spouses may by agreement convert community earmings into separate property so far as they are personally concerned but such agreements are not binding upon respondent [State Board of Social Welfare] in proceedings for determining the amount of aid to be awarded an apphicant. It is a truism familiar to all literate men that a spouse takes her mate in poverty and in wealth, in sickness and in health, so long as they both shall live.' The act providing aid for the aged would be a mockery if a wife could live in her mansion in abundance while scorning her husband in his chill penury or watching the state's beneficence molify his wretchedness." "The court's holding and statenent thus declare

5 Kelly v. State Board of Social Welfare, 99 Cal. App.2d 865, 222 P.2d 925 (1950). See also 4 Ors. Cat. Atr'y Gen. ns 126 5624, Aug. 22, 1944 and 4 Ops. Cal. Atr'y Gen. ns 413 5670, Dec. 29, 1944. In the latter it is said: "The Sections of the [Civil] Code just referred to are rules of property and not necessarily rules for the administration of aid to Needy Aged persons. These rules of property are necessary for the protection of property rights, but may be in many cases actual hindrances to the proper administration of public assistance laws, which must be liherally construed and administered with an eye single to the social problems involved. Public welfare officials are not determining property rights, but are ascertaining need and attempting to alleviate distress. In determining need and attempting to alleviate distress, a public welfare official cannot attempt a solution of the problem confronting him by the use of the lard and fast rules governing the contractual and property rights of the imdividuals involved." "The Legislature has provided a complete and practically self-sufficient system for the rendering of assistance to the needy and aged and the administration of this system is elaborately provided for in the Welfare and Institutions Code."

6 See Kelly v. State Board of Social Welfare, supra note 5 at 868, 222 P.2d at 926-927. Under CAx. Crv. CODE $\$ \$ 158,159$ there is no doubt that a husband and wife inay agree between themselves without any other consideration than their mutual consent that the wife's earnings shall helong to her as lier separate property. CAI. Crv. CODE \$157 adds: "Neither lusband nor wife has any interest in the property of the other." See 1 ARMstrong, Carmforma FAMTIX LaW 546. 
in effect that normal rules about community and separate income may be and are properly disregarded for welfare purposes by the Welfare and Institutions Code and the State Board of Social Welfare as the rule making authority under the welfare portions of that code.

It is therefore to the Welfare and Institutions Code that lawyers must turn to discover, for welfare purposes, what content has been given to family law provisions of the Civil Code and to what degree those provisions have been reversed, superceded or modified.

\section{Income-Community and Separate}

Under the Welfare and Institutions Code and pursuant rules and regulations, the normal community property rules with respect to income are set aside or modified in several important ways. In contrast with the usual, albeit not unvarying, judicial and legislative practice in dealing with the community property system, welfare provisions draw a line of distinction between income and property, define income restrictively, treat income derived from earnings differently from that derived from property, and distinguish earnings predicated on the presence of the earner in the labor market from other income.

Under welfare provisions, income may be counted as such only if it is currently available to meet needs, and if it is predictable or received with sufficient certainty and regularity to be counted on to meet the essentials of living. Security of the recipient in planning the necessary expenditures for his maintenance is the determinative factor. Income which is small in amount, merely potential, unpredictable either as to amount or time of receipt, and of short duration is not considered income. ${ }^{8}$

If the recipient of public assistance has community income fron current earnings, or from past employment, he may allocate to his spouse, without suffering a reduction in his aid grant, a reasonable amount necessary for the spouse's support, but not to exceed one-half of the income. Under normal community property rules the spouse would seem to be entitled to an allocation of one-half. ${ }^{9}$ However, no allocation of such income may be made for the support of minor children.

A similar divergence fron normal community property law is found in regard to the income of the ineligible spouse of the recipient. The spouse

7 The same result could not have been reached in the Kelly case, supra note 5, on the basis of CaI. CIv. CODE $\$ 171$ making the wife's property which is the gift of the husband hable for debts contracted to supply him with necessaries. Only half her earnings during inarriage would be such a gift; and, in any event, such property under CAz. Crv. CoDE $\$ 171$ is only liable for debts contracted, i.e., to the claims of third parties.

8 Old Age Security Manual A-1104, Aid to Needy Children Manual C-352, Aid to Needy Blind Manual B-532.

${ }^{9}$ CAL. Crv. Cone § 161a ("present, existing and equal" interests of husband and wife). 
may retain from his commumity imcome an amount sufficient to meet his needs and those of his minor children, though this amount exceeds one-half of the income. Different budgetary standards are applied to determine the amount necessary to meet the spouse's needs depending on whether the spouse is in or out of the labor market. ${ }^{10}$

A public assistance recipient who also receives Old Age and Survivor's Insurance is not required, and, in some circumstances, is not permitted to divide equally with the spouse. This is so even though the OASI premiums were paid out of commumity income and the OASI payments represent and take the place of earnings. Any amount of the OASI payment up to one-half may be apportioned to the spouse unless and until the spouse qualifies for OASI benefits and then the apportionment must cease altogether, though the benefits received by the spouse are far less than the payments to the recipient. The same rules apply to railroad retirement benefits. ${ }^{11}$

Community income made the separate income of the spouse by an otherwise valid joint agreement between the spouses must continue to be treated as community income if the transfer was made in order to qualify for aid or for a greater amount of aid. ${ }^{12}$

The recipient's separate income must be applied to meet his own needs and no portion of it may be allocated to the spouse whether eligible or ineligible for public assistance. A fraction of the separate income of an ineligible spouse is required to be allocated to the recipient according to a responsible relatives' scale in Section 2181 of the Welfare and Institutions Code.

Income from real or personal community property is required to be shared equally with the spouse, whether eligible or ineligible for public assistance. ${ }^{13}$

With one very important exception, the welfare rules respecting income of Old Age Security recipients and their spouses also apply to blimd aid recipients and their spouses. The exception arises out of a policy of encouraging blind aid recipients to become self-supporting. Consistent with the purpose, it moves away from the Welfare and Institutions Code conception of the family as a completely intergrated umit, with all income being available for the maintenance of any of the members. The exception consists of a provision that $\$ 50$ a month of the earnings of Aid to Needy Blind recipients, ${ }^{14}$ and $\$ 1000$ a year of the income of Aid to Partially Self-Supporting Bhind recipients plus 50 per cent of every dollar above that amount,

10 Old Age Security Manual A-1116, Aid to Needy Blind Manual B-538.

11 Ibid. and Old Age Security Manual A-1170, A-1171 and Aid to Needy Blind Manual B-572.

12 See note 10 supra.

13 Old Age Security Manual A-1116, Aid to Needy Blind Manual B-538.

14 CAL. Werf. \& Inst. Code $\$ 3084.3$, Aid to Needy Blind Manual B-540. 
shall be exempt from consideration in determining eligibility for aid or the amount thereof. ${ }^{15}$ The earnings in the one case and the income in the other are not in any part allocable to the spouse, even though, but for this provision, they would be community income. Above this exemption, only so much of the recipient's community earnings may be allocated to the spouse as are necessary to meet the spouse's needs, though that be far less than half. Thus, for example, suppose an ANB recipient, having a spouse receiving OAS, has earned income of $\$ 125$ a month. The spouse has a continuing special need for niedical treatnient of $\$ 15$ a month which the OAS grant is insufficient to meet. The first $\$ 50$ a month of the recipient's earnings is exempt from any consideration. He may allocate $\$ 15$ a month to his spouse to meet the medical need. The balance of $\$ 60$ is income to the ANB recipient and is taken into account in determining his grant.

In APSB, following the same rehabilitative objective, it is provided that educational scholarships "shall not be deemed property, income, or a resource for any purpose ...."16

The character of the aid payment itself engendered a controversy which only recently came to a head in a California Supreme Court decision. ${ }^{17}$ Los Angeles County instituted a practice of treating the aid payment as income to the family unit, one-half of which was legally available to the spouse. The claim of the needy spouse for county indigent aid accordingly was reduced or denied altogether. ${ }^{18}$ The California Supreme Court affirmed a trial court order forbidding the State Board of Social Welfare to interfere with the Los Angeles practice. ${ }^{19}$ The counties are thus left free to treat the state aid payment as community inconre. ${ }^{20}$

The Supreme Court reached this conclusion despite the explicit provisions of the Welfare and Institutions Code. The Code declares that aid payments are made solely and exclusively for the purpose of meeting the personal needs of the individual recipient. It provides that the aid grant shall be "absolutely inalienable."

15 CaL. Werf. \& Inst. Code $\$ 3472$, Aid to Needy Blind Manual B-542.

10 Cax. WexF. \& Inst. Code $\$ 3447$, Aid to Needy Blind Manual B-542. (1953).

17 County of Los Angeles v. State Social Welfare Department, 41 Cal.2d 455, 260 P.2d 41

${ }^{18} \mathrm{Cf}$. "[T] $]$ he right of eligible persons to receive assistance" is "inherent in the requirements of the Social Security Act for the development and operation of state plans." HANDBOoK of Public Adrinistration, Pt. IV § 2321.

19 See tenBroek and Wilson, County of Los Angeles v. State Social Welfare DepartmentA Criticism, 4I CarrF. L. Rev. 499 (1953).

20 County of Los Angeles v. State Social Welfare Department, 41 Cal.2d 455, 260 P.2d 41 (1953).

21 CAx. WeLF. \& Irst. CODE $\S \S 19,2006,2020$; Old Age Security Manual A-135, A-1200, A-1386, Aid to Needy Blind Manual B-020, B-605, B-607, B-609; see 42 U.S.C. $\S \S 6,1002$, $406,101(2)(a)(8)$. 


\section{Property-Community and Separate}

The relative interests of the spouses in comnunity and separate property, real and personal, as established by the general community property system, are also to a considerable extent disregarded for welfare purposes.

The Welfare and Institutions Code places a limit on the amount of real property a person may own and still be eligible for public assistance$\$ 3500$ county assessed valuation less encunibrances of record in OAS, ANB, APSB; $\$ 3000$ in ANC. ${ }^{22}$ In deterniming whether a person exceeds the limit, except in APSB, the spouse's share of the community real property is counted, and even the spouse's separate real property, if they are living together. ${ }^{23}$ The real property owned by recipients and/or their spouses generally consists only of a home and, if they are living together both have the use of it for shelter, regardless of its community or separate status. The distinctions in Civil Code Section 171 between various forms of the wife's separate property and the liability of only certain of them for the husband's necessaries are also disregarded. In case of legal separation or actual separation with intent to terminate the marriage, the spouse's separate real property is not included in determining the real property holdings of the applicant but the spouse's share of the community real property is included. ${ }^{24}$

The rule with respect to personal property is different. If the spouse is not also seeking public assistance, only the separate personal property of the apphicant and his share of the community are considered in determining whether he exceeds the limit allowed. Again, Civil Code Section 171 is ignored. If both spouses are applicants, the separate personal property of each, together with his share of the community personal property, is counted in determining the eligibility of the other. The value of "the combined total personal property holdimgs" of the couple is the determinative figure, without benefit of any distinctions between community and separate property. 25

In Aid to Partially Self-Supporting Blind, only the separate property of the applicant and his share of the community property is considered in determining whether he exceeds either personal or real property limitations. ${ }^{26}$

\section{OTHER PROPERTY MODIFICATIONS}

In other respects, too, property notions have been modified for welfare purposes by the Welfare and Institutions Code and the rules issued under it.

22 CAI. Welf. \& INST. Code $\$ \$ 2164 ; 3047 ; 3447 ; 1520$.

23 Old Age Security Manual A-703, Aid to Needy Blind Manual 406.

24 Ibid.

25 CAL. WELF. \& INST. Code $\$ \S 2163,3047.2$, Old Age Security Manual A-720, Aid to Needy Blind Manual B-442.

26 Car. Welf. \& Inst. Code $\$ 3447$, Aid to Needy Blind Manual B-412, B-442 (2). 
Free and unrestricted acquisition, possession, use and transfer of property-and thus in effect the right to property itself-has been drastically curtailed. The imposition of a property limit, both for real and personal property, existing as a condition of eligibility, tends to operate negatively on accumulation of property by recipients and, in cases of necessity, to compel liquidation of property for consumption purposes before eligibility is reached. ${ }^{27}$ As a means of enforcing and implementing the property ceiling idea, transfers of property by prospective applicants in order to become eligible and by recipient to remain eligible or increase the amount of the aid grant are forbidden. ${ }^{28}$ If such transfers are effected, they result in ineligibility until the value of the property transferred would have come within the allowable limits if it had been used to meet the needs of the applicant or recipient at a rate of consumption fixed by the State Board of Social Welfare. ${ }^{29}$

More active and pervasive than the property eligibility condition is the policy of utilization: a requirement that real property be used to meet current needs of the applicant or recipient. The requirement does not apply to the separate real property of the ineligible spouse [or to the spouse's share of the community]. It does not apply to APSB recipients at all. Utilization has been made mandatory upon the states by the Federal Social Security administrators, founding it on the clause of the Social Security Act which says that a "state agency shall, in determiming need, take into consideration any other ... resources" of the applicant. ${ }^{30}$ The utilization requirement is complied with when the real property provides the applicant or recipient with shelter, food or other maintenance items or produces reasonable net income for the purpose of such items. A dwelling used by the recipient as a home, together with reasonable yard space around it, is utilized. Farm acreage must be worked to a reasonable standard of productivity, rented for the going rate for such land in the vicinity, or sold at the market price. City building lots must be sold at their reasonable market value; apartments and houses not occupied by the recipient rented or sold; and so on. The resource must be utilized according to the plan which will make the greatest contribution toward the recipient's current needs. Real property must be sold if it cannot otherwise reasonably be utilized unless the sale would be a useless act, i.e., would result in a sales price which when added to the personal property holdings of the recipient and/or his spouse would not exceed the limit placed on personal property. ${ }^{31}$

27 See note 25 supra.

28 CAx. WeLF. \& Inst. Code $\$ 2160(\mathrm{~g})$, Old Age Security Manual c. VIII, A-800, Aid to Needy Blind Manual B-490, Aid to Needy Children Manual C-345.

20 Old Age Security Manual A-880.

3042 U.S.C. $\$ \$ 302$ (a) (7), 1202 (a) (8).

31 Cat. WeLf. \& INST. Code $\$ \$ 2164,3047,1520$, Old Age Security Manual A-715, Aid to Needy Children Manual C-322. 
Transfers made in order to avoid the utilization requirement are forbidden under the same sanctions as transfers to avoid the property ceiling.

Still another change in normal property concepts brought about for welfare purposes by welfare law is a broadened definition of real property. Real property is defined to include "any place of abode of an individual, whether house, boat, trailer, or other habitation." ${ }^{32}$ It also includes stock in a water company not appurtenant to the land ownership of which is necessary to obtain water for agricultural purposes. ${ }^{33}$ Proceeds from the sale of real property which are retained for the purchase of a home "represent real property" for a period of six months from receipt. ${ }^{34}$ In APSB, proceeds received by a recipient from the involuntary conversion of real property are considered real property for a year. ${ }^{35}$

While the category of real property is thus eularged by additions of what normally would be personal property, the category of personal property is still further diminished by certain flat exclusions. Not to be counted as personal property are: (1) personal effects, such as clothes, household furniture and equipment, foodstuffs, fuel, and personal jewelry used by the applicant or held for his future use; (2) funds held in escrow revocable only upon consent of all parties involved; (3) life, burial or other insurance policies having no cash surrender value; (4) in ANC only, items which are part of a program of rehabilitation for a parent or of a program to assist in the maintenance and self-support of the family. ${ }^{36}$ On the other hand, in APSB the county assessed value of personal effects is taken into consideration. ${ }^{37}$

\section{RESPONSIBILITY OF RELATIVES}

The support obhgations of husband and wife have already been discussed. Under the Civil Code, they are contractual and mutual. They are not, however, reciprocally identical. They are intricately entangled with community income and property doctrines. The husband's obligation is penally enforceable. Under the Welfare and Institutions Code and pursuant rules, the support obligations of husband and wife are identical. Many categories and distinctions not in the Civil Code are invoked. Relevant Civil Code community property doctrines are ignored or modified. The Welfare and Institutions Code and pursuant rules, to some extent, im-

32 CAt. Welr. \& Inst. Code $\$ \S 2163.7,3047.27$, Old Age Security Manual A-710, Aid to Needy Blind Manual B-403, Aid to Needy Children Manual C-302.

33 Ibid.; and CAL. WeIF. \& INST. CODE \$§ 2163.4, 3047.24.

34 CAL. WeIF. \& INST. Code $\S \S 2165$ (d), 3047.3, Old Age Security Manual A-705, Aid to Needy Blind Manual B-457. Does not apply to Aid to Needy Children.

35 Aid to Needy Blind Manual B-3447.3.

36 CAI. WeIF. \& INST. CODE $\$ \S 2163.2,3047.21,1521.2$, Old Age Security Manual A-730, Aid to Needy Blind Manual B-454, Aid to Needy Children Manual C-327 A.

37 For more specific details, see CAL. WEIF. \& INST. CODE $\$ \S 3447,3447.1$. 
plement and fill out the content of Civil Code provisions. In other respects, they differ from the Civil Code provisions. In still others, they contradict them.

There are other support provisions of the Penal, Civil and Welfare and Institutions codes which are similarly supplementary, divergent and conflicting. The welfare phrase used to cover these obligations is responsibility of relatives.

\section{Parents and Adult Children}

Section 206 of the Civil Code provides: "It is the duty of the father, the mother, and the children of any poor person who is unable to maintain himself by work, to maintain such person to the extent of their ability. The promise of an adult child to pay for necessaries previously furnished to such parent is binding." Penal Code Section 270(c) states: "Every adult child, who having the ability to do so, fails to provide necessary food, clothing, shelter, or medical attendance for an indigent parent, is guilty of a misdemeanor...."

These two sections are obviously not identical in scope. The penal sanction is applied only to adult children. The civil obligation extends to parents and children of any age. In the Penal Code section the items of support are listed: "necessary food, clothing, shelter or medical attendance." The Civil Code section leaves the obligation general: "to maintain such person" or "to pay for necessaries." Under the Penal Code, the duty of the adult child runs to the "indigent parent." Under the Civil Code, the obligation runs to a "poor person who is unable to maintain hiniself by work." The Penal Code thus refers only to the condition of poverty without any regard to the circumstances whicl brought it about. Under the Civil Code, the person must be "poor" and "unable to maintain himself by work." Does "unable to maintain himself by work" cover all or only some of the following: physical or mental incapacity; unemployment due to general hard times; unemployment due to technological changes; due to lack of aptitude or training for such jobs as there are in the community; due to racial prejudice? Both the Penal and Civil Code sections limit the obligation to the specified persons having the ability to discharge it.

The Civil Code section has been held: to be enforceable by any appropriate judicial proceeding, though no method of enforcement is specified in the statute; ${ }^{38}$ to give an incapacitated adult child the right to obtain a support order directed against his father; ${ }^{39}$ to impose an obligation which is individual and several rather than joint; ${ }^{40}$ and hence not to authorize an

38 Paxton v. Paxton, 150 Cal. 667, 670, 89 Pac. 1083, 1084 (1907).

39 Ibid.

40 Garcia v. Superior Court, 45 Cal. App.2d 31, 36, 113 P.2d 470, 472 (1941). 
indigent parent, supported by one child, to bring suit to force the other children to bear their share; ${ }^{41}$ and that a mother does not have to be "absolutely destitute" in order to obtam support. ${ }^{42}$

Presumably the obligation under both the penal and civil code sections could be met by supplying aid in kind, i.e., by supplying the food, clothing and shelter say in the home of the adult child, rather than by supplying money wherewith the indigent person might purchase these items.

Under the Welfare and Institutions Code and pursuant rules, the spouse, parents and adult children of a blind aid recipient are the legally liable relatives. ${ }^{43}$ Under the aged program, only the spouse and adult children are liable. ${ }^{44}$ Since sixty-five is the age of eligibility, not many OAS recipients have living parents. Some do, however, and these are relieved of responsibility under the Welfare and Institutions Code. The Civil Code makes no such distinction as to parents on the basis of the degree of adulthood of their children. ${ }^{45}$

Under the Welfare and Institutions Code and pursuant rules regarding OAS recipients, responsibility rests first with the spouse and then with the adult children. Under the blind program responsibility rests first with the spouse, then with the parents and thereafter with the adult children. ${ }^{40}$ The maximum liability for two persons is the same as for one ${ }^{47}$ hence, full support of one parent discharges an adult child of responsibility toward the other. Marriage of the adult child does not relieve him of responsibility though it may very well affect the amount of his required contribution. ${ }^{48}$ Before his liability towards his parent begins, he is entitled first to support himself, his dependent spouse and minor children. ${ }^{40}$

Distinctions are drawn between married sons and daughters. Welfare and Institutions Code Section 2181, as amended in 1953, reads: "Income of a responsible relative is defined as the sum of income constituting the separate property of the responsible relative, the income (excluding earnings) which is community property subject to the control of the responsible relative and the earnings of the responsible relative but not of his or her spouse." The rules and regulations accordingly provide that the liability of the married daughter for the support of her parents extends to (a) her earnings and (b) income constituting her separate property. The re-

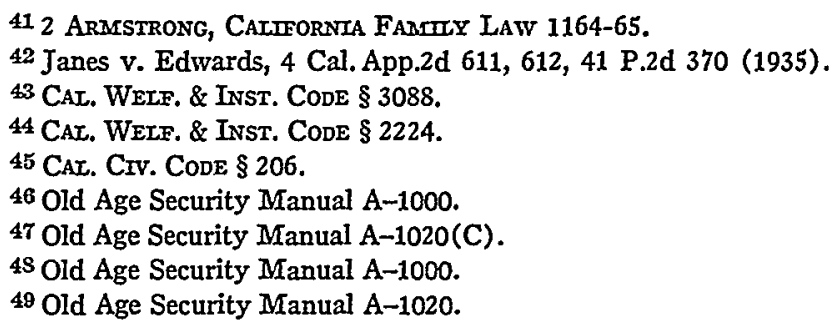

412 ARMSTrong, CALIFORNIA FARIIY LAW 1164-65.

42 Janes v. Edwards, 4 Cal. App.2d 611, 612, 41 P.2d 370 (1935).

43 CAL. WeLF. \& INST. CODE $\$ 3088$.

44 CAI. WELF. \& INST. CODE § 2224.

45 CAI. CIv. CODE $\$ 206$.

46 Old Age Security Manual A-1000.

47 Old Age Security Manual A-1020(C).

48 Old Age Security Manual A-1000.

49 Old Age Security Manual A-1020. 
sponsibility of the married son for the support of his parents extends to (a) his own earnings; (b) income constituting his separate property; and (c) income which is commumity property subject to his direction and control. Normally, of course, the earmings of the married son or daughter are commumity property. The 1951 amendment to the Civil Code ${ }^{50}$ giving the wife management and control of her earnings expressly declares that the section shall "not be construed as making such money the separate property of the wife, nor as changing the respective interests of the husband and wife" therein. The married daughter's liability thus extends to the community interest of the son-in-law in her earmings; and the married son's liability extends to the daughter-in-law's community interest in his earnings and in other community income wlich is subject to his control.

The most important of the changes in the support obligations of responsible relatives is that the obligation has been translated into financial terms and tabulated in detail; and the items of need and standards of living of the person in favor of whom the obligation is created are specified in detail. Both of these matters are therefore removed from the administration and the discretion of the courts. In one sense, these provisions are elaborations and implementations of Civil Code Section 206 and Penal Code Section 270-C: they spell out in minute detail the meaning of the responsible relative's ability to pay and of the words "indigent parent" or "poor person who is unable to maintain himself by work" as those words are used in those sections.

The pecuniary hability of responsible relatives is set forth in a table contained in Welfare and Institutions Code Section 2181. Maximum monthly contributions are specified on a basis of monthly net inconie and the number of persons dependent on it. Thus, for example, an adult clild who lias a net monthly income of $\$ 500$ and who is smgle and without children is liable to contribute a maximum of $\$ 60$ to the support of his parents; if he is married, $\$ 40$; if he is married and has one cliild, $\$ 30$; two children, $\$ 20$; three children, $\$ 10$; four children, nothing. A single person with no children and a net monthly income of $\$ 200$ or less is liable for no contribution.

The amounts specified in the table are the maximum liability. The county is required to give due consideration to the particular financial circumstances of individual responsible relatives. In unusual cases, contributions at less than the amount fixed by the scale may be perinitted by the board of supervisors. ${ }^{51}$

Civil Code Section 206 creates a statutory support obligation which

60 Cax. Crv. COde $\$ 171$ (c).

51 In 1953, CAI. WELF. \& INST. CoDE $\$ \$ 3088$ and 3474 were amended so as to fix the degree of liability of responsible relatives of blind aid recipients according to the table contained in CAL. WELF. \& INST. CODE $\$ 2181$. Prior to that time, the degree of responsibility of such relatives was left up to the county board of supervisors. 
comes into existence whenever the governing conditions occur. A judicial deternination is not a prerequisite, and, so far as the language of the section is concerned, judicial support orders can be retroactive. Under the Welfare and Institutions Code on the contrary, liability of responsible relatives may not antedate an administrative finding by the board of supervisors. ${ }^{52}$

The right to public assistance is in no way contingent upon relatives discharging their financial responsibility. ${ }^{53}$ If the relatives do not make the required payments to the aid recipient, the state must fill the gap and then recover from the relatives. If the relatives do make the contributions, the state reduces its allotnient accordingly. The actual receipt of the money by the recipient is the governing factor, not the existence of the obligation on the part of the relative or his ability to discharge it. ${ }^{54}$

Final enforcement action is assigned to the district attorney. $\mathrm{He}$ is obliged, at the demand of the board of supervisors, to bring an action to recover for the county the portion of aid payments for wlich the relative is responsible. ${ }^{55} \mathrm{~A}$ finding of ability to pay must be made by the board of supervisors or its authorized representative. ${ }^{56}$ In the case of responsible relatives of blind aid recipients, the law authorizes but does not require such recovery or enforcement action. ${ }^{57}$ Moreover, the power conferred on the administrators finally to determine ability to pay in the case of responsible relatives of OAS recipients is explicitly withheld under the blind program.58

The needs of the recipient and the standard at which they are to be met - which also determine the extent of the support obligation of pecuniarily able responsible relatives-are divided into basic and special needs. Basic needs are those continuing needs common to all recipients: food, housing, utilities, clothing, household maintenance and replacements, transportation and incidentals. They are legislatively presumed to cost $\$ 80$ per month for aged persons and $\$ 90$ for blind persons. ${ }^{59}$ Special needs are those needs which are not common to all recipients and which arise out of impairment of health, physical landicap, or other circumstances peculiar to the individual. They include, for example, special diet, special housing requirements, and additional utilities. The actual cost of these items within certain

52 Car. Welf. \& Inst. Code § 2224, Old Age Security Manual A-1090, Aid to Needy Blind Manual B-589.

53 CAC. WeLF. \& INST. CODE $\$ \$ 2224,3088,3474$.

54 CAT. WeIf. \& INST. CODE $\$ 2160(f)$.

55 Cax. WeLf. \& INST. CODE § 2224.

56 Ibid.

57 CAC. WerF. \& INST. Code $\$ \S 3088,3474$.

$58 \mathrm{lbid}$. Query: Now that the responsible relatives of the blind are subjected to the contribution scale in CAL. WELF. \& INST. CODE $\$ 2181$, is the discretion conferred on the courts also governed by that scale?

59 CAI. WeIF. \& INST. CODE \$§ 2020, 3084. 
ceilings is allowed in the budget. The total cost of meeting basic and special needs is the amount to which an individual is entitled from his relatives if they are pecuniarily able.

\section{The Aid Recipient as a Responsible Relative}

What are the responsibilities of an aid recipient towards parents or dependent adult children? Is his aid payment or other income liable for the discharge of the support obligation created by Civil Code Section 206? Is eligibility for public assistance under the Welfare and Institutions Code and pursuant rules the measure of inability under Civil Code Section 206 which exempts from the obligation to support? The answers to these questions have been worked out in the provisions of the Welfare and Institutions Code and welfare department rules, not in terms of reconciling the codes but in terms of the paramountcy of the Welfare and Institutions Code when there is conflict. The conditions under whicl public assistance may be received, the purposes for which it is granted, the needs which are intended to be met are determined by welfare law. With a few exceptions, the central principle is that aid is individually granted to meet the personal needs of the recipient, not the composite needs of his family unit or the individual needs of other family members. The rules therefore provide that "a legally responsible relative who received public assistance shall not be held liable for a contribution from his grant of aid to other persons for whom he is legally responsible." 60

On the same principle, the rules provide that the total amount of a recipient's separate income shall be applied towards his own needs ${ }^{61}$ and that no person is liable for the support of another until he is first able to maintain himself. ${ }^{62}$

The application of these rules and their possible conflict with Civil Code Section 206 were before the State Board of Social Welfare in a recent appeal. The appellant recipient sought to allocate crop income of $\$ 500$ to his adult mentally incompetent son. The hearing officer, relying on Civil Code Section 206 and the supreme court's interpretation thereof in Paxton v. Paxton, ${ }^{63}$ recommended that the Board hold: that the appellant, being under a legal duty to support his inconipetent son, must of necessity devote available income to the discharge of that duty; that the appellant's receipt of OAS does not alter that necessity; and that the income thus consumed in the discharge of a legal duty cannot be utilized by the appellant for his own needs or counted by the county in figuring his grant. The Board, how-

60 Old Age Security Manual 1020, Aid to Needy Blind Manual B-582.

61 Old Age Security Manual A-1116.

62 Old Age Security Manual 1020.

03150 Cal. 667, 89 Pac. 1083 (1907). 
ever, declined to accept the hearing officer's recommendation and held that Civil Code Section 206 was either inapplicable by virtue of its language or irrelevant as superceded by the Welfare and Institutions Code. ${ }^{64}$

\section{Responsibility of Parents for Minor Children ${ }^{65}$}

The support obligation of parents for minor children is spelled out in a large number of Civil Code sections and one Penal Code section. ${ }^{68}$ Despite some confusion in the sections, it is clear that: (1) The primary responsibility of support of a legitimate child rests upon the father; that if the father is not able, for whatever reason, to give adequate support, the mother's obligation then arises and consists of assisting the father in the discharge of the duty to the extent of her ability. ${ }^{67}$ (2) In the case of an illegitimate child, the responsibilities of the father and mother are more nearly equal. The emphasis in Civil Code Section 196(a) on the right of the mother or guardians appointed with her consent to institute suit against the father for the child's support, rather than indicating primary responsibility on the father, betokens the mother's earlier exclusive responsibility. Thus also the language "the father as well as the mother" in the section indicates that the father's responsibility is added to the already existing obligation of the mother. ${ }^{\text {s }}$ The words used are without distinction as to the primary or secondary character of the duty imposed or presupposed. (3) If the normal family situation is disturbed or ceases to exist, the primary, equal or subordinate responsibilities of the father and mother may all be shifted. Thus, if either the husband or wife brings an action "for the exclusive control of the children" ${ }^{\prime 9}$ or for. separate maintenance ${ }^{70}$ or for divorce $^{71}$ a completely new and different allocation of responsibilities for the support of the children may be made either on a permanent basis or temporarily during the pendency of the actions. ${ }^{12}$ (4) The mode of enforcement is by civil action and continuing judicial control. (5) The court is left absolutely free to determine the manner in which the support will be supplied and the degree of the liability. No standards or guides whatever are laid down in the statutes. (6) The court is only slightly less free to determine what the child is entitled to receive. Support, maintenance and education are mentioned in the sections, sometimes qualified by "suitable to his circumstances." But the items of support are not given nor are spe-

e4 Minutes, State Board of Social Welfare, Jan., 1953, p. 154.

65 See 1 Armstrong, CartFornta FammLY Law c.X.

66 Car. Crv. Code $\S \S 196,196$ a, 199, 137, 137.1, 137.2, 139, 143; Cax. Pen. Code $\$ 270$.

67 CAI. Crv. CODE $§ 196$.

68 Cal. Crv. Code $\S 196 a$.

69 Car. Crv. Code $\$ 199$.

70 Car. Crv. Code $\S \S 137,139$.

71 Cal. Crv. Code $\$ 139$.

72 CaI. CIv. Code $\$ 137.2$. 
cific standards by which they are to be met. (7) If there is both community and separate property available for the support of children, the judge is specifically given discretion to determine in what proportions they shall be used. $^{73}$ (8) The support obligation made criminally enforceable under Penal Code Section 270 coincides in major respects with the civil obligation in Civil Code Section 196. The father's responsibility is primary; the mother's secondary. Moreover, the scope of the father's liability is practically identical under both sections. Death, mental and physical infirmity expressly exempt him from liability under Penal Code Section 270; and insufficiency of funds is a defense against criminal prosecution. ${ }^{74}$ Inability to give adequate support - whether arising from death, mental or physical infirmity or financial inability-exempts the father from liability under Civil Code Section 196. From there on the Penal and Civil Code sections diverge and conflict. The mother's obligation comes into being under Penal Code Section 270 only if the father is unable to discharge his liability through death or mental or physical infirmity. Though the father's financial incapacity is a defense to hin against criminal prosecution, it does not inaugurate the mother's criminal liability as it does her civil liability under Civil Code Section 196. Unlike Civil Code Sections 196 and 196(a), Penal Code Section 270 puts legitimate and illegitimate children upon the same footing. Penal Code Section 270 disregards the arrangement of parental responsibility for illegitimate children provided in Civil Code Section 196(a). Moreover, under Penal Code Section 270, the father's obligation continues quite regardless of its civil reallocation under other Civil Code sections mentioned above. It is expressly stated to exist whether the parties are married or divorced, "regardless of any decree made in any divorce action relative to alimony or to the support of the child," even though the mother is legally entitled to the custody of the child, and even though the mother or anybody else furnishes support. Under the Penal Code as under the Civil, the character and extent of the liability in any given case is left up to the court; as is the standard of care of the child, although the list of items to which the child is entitled has now been stretched to include "necessary food, clothing, shelter, or medical attendance or other remedial care."75

T3 CaL. Crv. Code $\S 143$.

74 People v. Wallach, 62 Cal. App. 385, 217 Pac. 81 (1923) ; People v. Caseri, 129 Cal. App. 88, 18 P.2d 389 (1933) ; 2 Ararstrong, Calmornia Fammi Law 1143.

75 Under CaL. Crv. CODE § 211, "The parent, whether solvent or insolvent, may relinquish to the child the right of controlling him and receiving his earnings. Abandonment by the parent is presumptive evidence of such relinquishment." Such relinquishment is called emancipation. Thus, according to this section, parents are free to emancipate their children at any time and for any reason they see fit and quite regardless of their solvency or insolvency. $C f_{\text {, }}$, the welfare rule that if the emancipation is made for the purpose of qualifying a member of the family for aid or for a greater amount of aid than that to which they would otherwise be entitled, such emancipation shall be considered ineffectual. Aid to Needy Children Manual C-356 C; Aid to Needy Blind Manual B-594. 
The Civil Code and Penal Code provisions dealing with the responsibility of parents for minor children are thus relatively more numerous and detailed than the sections in those codes concerming other phases of the support obligation. Correspondingly, the provisions of the Welfare and Institutions Code, while not less numerous, are far less specific and particular. Precise legislative standards, guides and directions are conspicuous by their absence when comparison is made with the aged and blind programs. Delegation of policy determining, rule making and administrative authority is proportionately greater. The source of this difference between the Aid to Needy Children program on the one hand and the aged and blind programs on the other, is not difficult to find. The latter two evolved under the pressure and with the participation of articulate and organized groups of the aged and blind. These groups sought always to fix the conditions of eligibility, the amount of the grant, the contributions required of responsible relatives and other requirements in the statute itself, thereby to reduce the number of factors subject to individual variations and the social workers' judgment. The needy children are, of course, unorganized, voteless and voiceless. In the development of their program welfare officials, state, county and national, played a larger role. Their emphasis was upon a system less rigidly statutory in character in which administrative flexibility, policy judgments and individual case worker evaluations are principal features.

The Welfare and Institutions Code provisions dealing with the ANC program specify the items of need which are to be met. They thus repudiate the concept embodied in Civil Code Section 196 that support must be suitable to the child's circumstances. The items of need are these: "(a) Safe, healthful lousing. (b) Minimum clothing for health and decency. (c) Low cost adequate food budget meeting recommended dietary allowances of the National Research Council adapted to prices of the area in which the recipient resides. (d) Utilities in accordance with the basic minimum need. (e) Other items verified as needed, including household operation, education and incidentals, recreation, personal needs, and insurance but not to exceed in any one month [specified] amounts. ${ }^{76}$ (f) Allowance for essential household furniture and equipnient. (g) Allowance for essential medical, dental, or other remedial care when not available through a public facility. (li) Allowances for special needs for any one or more of the following items: special diets upon the recommendation of a plysician, transportation, laundry, housekeeping service, and telephone; and utilities

${ }^{76}$ Number of needy children: 1 child $-\$ 13 ; 2$ children- $-\$ 15 ; 3$ children- $-\$ 18 ; 4$ children $-\$ 21 ; 5$ children $-\$ 24 ; 6$ children $-\$ 26 ; 7$ children $-\$ 28 ; 8$ children $-\$ 30 ; 9$ children $-\$ 32$; 10 children $-\$ 33 ; 11$ children $-\$ 34 ; 12$ or more children- $-\$ 35$. 
in excess of the basic minimum need." ${ }^{77}$ These items are defined and interpreted in an elaborate set of administrative rules and regulations. ${ }^{78}$

The statute explicitly directs the department to determine the standards of assistance. "Minimum basic standards of adequate care shall be distributed to the counties and shall be binding upon them. Such standards shall be determined by the rules and regulations of the State Department of Social Welfare, approved by the State Board of Social Welfare . ..."79 "The State Department of Social Welfare shall: (a) make rules and regulations for the proper maintenance and care of needy children; (b) make rules and regulations for the administration of aid to needy children." 80

If a child is deprived of parental support, i.e., of these items at the standard fixed by the Welfare Department, by reason of the death, continued absence from the home, or mental or physical incapacity of one or both parents (natural or adoptive, married or unmarried); the child is eligible for public assistance. ${ }^{81}$ Mere financial inability of the parent remaining in the home, whether due to general unemployment or other factors not constituting mental or physical incapacity, does not give rise to eligibility of the child, though his need be acute. A child could be deprived of parental support or care and, because of incoine, not be in need, or he could be needy but not deprived of parental support or care. Absence from the home is not "continued" unless it is for a period longer than three months. ${ }^{82}$ Any resources of the remaining parent, whether father or mother, must be utilized to meet the needs of himself or herself and the child in order to be or remain eligible.

Without regard to the distinctions taken in the Civil Code sections, Department rules declare parents to be responsible for the support and care of their children, natural or adopted. Again without regard to Civil Code distinctions the rules provide that if both parents are absent the total financial resources of both slall be determined. This determination is to be made by the county welfare department and a number of guides or pertinent factors are listed. ${ }^{83}$

The rules provide that if the absent parent is under recent court order to contribute, the county shall accept the findings of the court as the de-

77 CAL. WeLF. \& INST. CODE § 1511.5.

78 Aid to Needy Children Manual C-500.

79 CAL. WELF. \& INST. CODE $\$ 1511.5$.

80 CAL. WeLF. \& INST. CODE $§ 1560$.

81 CAI. WEIF. \& INST. CODE $\S 1500$.

82 Ibid.

83 (1) Living plan (whether maintaining a household, boarding, paying rent and taking meals out, etc.) ; (2) Income; (3) Monthly expenditures necessary for maintenance, such as: (a) costs of food, shelter, clothing, etc., (b) expenses incident to employment, (c) cost of support and care of other dependents, (d) legal obligations, debts, medical and dental needs, etc. See Aid to Needy Children Manual C-366. 
termination of his ability to contribute. Thus the welfare department accepts a prior judicial determination of ability to pay as a discharge of its duty to make a decision.

Enforcement of relatives' responsibility is initially a duty of the county welfare department. It must secure from the remaining parent, the children or other sources such information as it can about the absent parent or parents, must discover their whereabouts and contact them if possible, must evaluate their financial situation and ability to pay and prevail upon them to make monthly contributions in the amounts so determined to be due. All state, county and local agencies are required to cooperate with the county welfare department in the location of absent parents. ${ }^{84}$ If the welfare department's efforts prove unavailing, however, the district attorney or other law enforcement officer of the county is brought into the case. Under Welfare and Institutions Code Section 1552.4 the board of supervisors must "immediately notify the district attorney whenever aid is granted to a child who is not being supported by a parent unless it is defimitely established that the parent is financially incapable of providing such support." The welfare department is required to cooperate with the district attorney and to supply him with all case-record information related to the question of non-support and the suitability of prosecution as a method of obtaining support. The district attorney is directed to take all necessary steps to secure the support. The remaining parent, under penalty of denying the child aid, must give "reasonable assistance" to law enforcement officers in the enforcement of the absent parent's obligation. ${ }^{85}$

The rules issued pursuant to Welfare and Institutions Code Section 1552.4 provide that the absent parent may be determined to be clearly unable to supply support, or is currently contributing to the best of his ability, and the district attorney, consequently, need not be notified, if (1) he is receiving public assistance; (2) he is in a mental or penal institution; (3) there has been no substantial change in the circumstances since a legal determination of his ability to support has been made; (4) the county has determined that his income and resources are so limited that lie is unable to contribute.

\section{Stepfathers}

Under a long-standing policy of the common law, stepfathers are not liable for the support of stepchildren. The Civil Code, however, makes it doubly certain in California by an express declaration that: "A Inusband is not bound to maintain his wife's children by a former lrusband; but if he receives them into lis family and supports them, it is presumed that he

84 CAL. WeLf. \& INST. CODE $\$ 1552.6$.

85 CAL. WELF. \& INST. CODE $§ 1523$. 
does so as a parent, and, where such is the case, they are not liable to him for their support, nor he to them for their services." 86

Quite regardless of the presence or absence of legal hability, most stepfathers do support their stepchildren. As a practical matter, they can hardly avoid it. They all live under the common roof, view the common television and the stepchildren cannot very well be driven from the table when the parents and other children are eating.

To supply a legal obligation binding on the minority of stepfathers who do not wish to support their stepchildren and can find a way of avoiding it, a move to write stepfather responsibility into the Welfare and Institutions Code developed im the legislature. The proponents of such an amendment took the position that a man who marries a woman with children does so with his eyes open and thus voluntarily assumes the relation and the obligation of a parent. His moral duty of support, consequently, is only less than that of the natural father. The opponents of the amendment mamtained that to change the Civil Code policy and impose liability would discourage men from inarrying women with children and thus deter re-establishment of normal parental, family and home relationships for the children.

In the end, at the 1951 session of the Legislature a self-contradictory compromise measure was passed which amended Welfare and Institutions Code Section 1508 to make eligibility of stepchildren for Aid to Needy Children payments depend upon the mability of the stepfather to support them. However, if the stepfather was able but unwilling, the eligibility of the stepchildren for ANC was not affected. ${ }^{87}$

In the sprimg of 1953, the Legislature had another try at resolving its differences and working out a stepfather policy. This time, an amendment to Welfare and Institutions Code Section 1508 was passed which unequivocally established the legal obligation of the stepfather and eliminated the element of willingness. "Notwithstanding the provisions of Section 209 of the Civil Code," the new amendment read, "a stepfather is bound to support, if able to do so, his wife's children if without support from such stepfather they would be needy children ehigible for aid under this chapter." A ceiling was placed upon the obligation-not to exceed "the wife's commumity property imterest in his mcome."

Withm the specified maximum, the Legislature could not agree as to

80 CAL. Crv. Code $\S 209$.

87 The division in the State Welfare Board was equal to that in the legislature. As a result, rules and regulations were issued that were as ambiguous and contradictory as the legislation they were designed to enforce. Hearing officers, trying to apply thein, came out with widely varying results in similar or identical cases. The counties quite generally held the children ineligible if the stepfather hived in the hoine and they adjudged him able to support. Thus, they ignored the willingness element exphitity present in the legislation and, in effect, outdistanced the legislature in imposing stepfather liabilty. 
the degree or measure of the stepfather's obligation. Legislative direction to establish that was left with the State Welfare Board. The legislative history, however, made it clear that something more generous than the ANC standard and less generous than no liability at all was intended. The State Welfare Board, therefore, steered a middle course. Simce the ANC budget for a family of four is about $\$ 2400$ a year, and the BLS city worker's budget is roughly $\$ 4400$, rules were devised and put into effect wlich would allow the stepfather family of four $\$ 3480$ before his liability to the children began- $\$ 210$ a month for limself and wife, and $\$ 40$ a month for each child. Experience under the formula, however, indicated that, in some cases, it was more generous to the stepfather than the counties had been under the earlier more flexible situation; ${ }^{88}$ and, as a result, in these cases, the ANC grant had to be mcreased. The Social Welfare Board therefore, at the prodding of the department staff and county welfare departments, in December, 1953, put into effect the current rule. It provides that in determining the stepfather's ability to contribute to the support of the stepchildren, there shall first be deducted from his net income ten per cent of his gross earnings or of his net income if self-einployed, plus the amount of contributions actually made for the support of his dependents living out of the home. ${ }^{89}$ The mother's total net separate income and the community incoine consisting of her earnings is considered income to the family budget unit; unless the stepfather does not have sufficient income to meet lier needs as well as his own and those of his dependents. If this is the case, the nother's mcome is first applied to meet ler needs and the remainder is divided, equally among her children, including her children by the stepfather. ${ }^{90}$

A number of points with respect to the 1953 amendment of Welfare and Institutions Code Section 1508 should be noted:

(1) Civil Code Section 209 is left unimpaired in its general application. The stepfather's obligation created under Welfare and Institutions Code Section 1508 exists only as to stepchildren who, without his support, would be eligible for Aid to Needy Children.

(2) The stepfather's obligation under Welfare and Institutions Code Section 1508 is limited by his ability. The limitation is stated without qualification and hence presumably applies whatever the character or origin of the inability.

(3) The stepfather's ability to support the stepchildren is to be determined administratively under regulations set forth by the State Department of Social Welfare. The administrative discretion is only slightly quali-

88 Ibid.

89 Aid to Needy Children Manual C-356 and 364(B).

90 Aid to Needy Children Manual C-364(B). 
fied. The amount of Aid to Needy Children grant, says the section, shall be computed "after consideration is given" to the stepfather's income. The determination of whether the stepfather "is able to support the child either wholly or in part" "shall be based upon a standard which takes into account the stepfather's income and expenses." Clearly, the "expenses" which are to be taken into account are not merely those in connection with securing the income. Otherwise, the earlier sentence would have required "consideration" of both income and expenses. Can the Board disregard any expenses which the stepfather actually has-whether for luxury items or essentials, for debts not yet incurred at the time of commencing aid or marrying into the family or for court ordered alimony to a previous wife? If the obligation imposed by the section is to mean anything, the department must determine what expenses are to be taken into account at face value and those that are to be discounted or not counted at all.

(4) The phrasing of the stepfather's maximum liability under the obligation-not to exceed "the wife's community property interest in his income" - is very curious. It sounds more like an argument than a command, as if to say: "We are really only granting the wife what is due her under commumity property rules and imposing no new obligation on the stepfather." The phrasing also illustrates the fallacy of invoking in welfare laws legal concepts from other fields. Suppose the stepfather and prospective wife enter into a pre-nuptial agreement that his earmings shall be his separate property-does she then have any "commumity property interest" in them? Suppose his income is ample but derived, not from current activity, but from past investments, insurance, pensions, or annuities-should this affect his liability as it obviously unust under the phrasing employed? The expression, "not to exceed one-half of his income" would have been more simple, direct and effective.

(5) Civil Code Section 209 says: "A husband is not bound to maintain his wife's children by a former husband." Welfare and Institutions Code Section 1508 refers only to "his wife's children," omitting the words "by a former husband." It is thus clear that the stepfather's obligation under Welfare and Institutions Code Section 1508 extends to illegitimate as well as to legitimate children of his wife.

(6) If a needy child lives apart from his mother and stepfather, the stepfather is not bound to support him.

(7) The natural father is not reheved of any obligation to support his children by the liability imposed upon the stepfather.

(8) While the stepfather's obhigation under Welfare and Institutions Code Section 1508, within his ability, is absolutely stated, no civil, judicial or other sanctions are mentioned. Enforcement alternatives are thus three: (a) Apply the doctrine of the Paxton case, under which any appropriate 
legal action might be brought to enforce a support obligation when no mode of enforcement is specified..$^{91}$ (b) Leave enforcement to the welfare administrators who might act by denying Aid to Needy Children to the stepchildren to the extent of the stepfather's liability. This mode of enforcement would violate the fundamental purpose of Aid to Needy Children, namely, to get relief to those who need it. It would violate, moreover, the principle, uniformly estabhshed elsewhere throughout the Welfare and Institutions Code with respect to relatives' responsibility, that the grant of aid is not made contingent upon the relatives making the contribution for which they are liable. (c) Proceed on the understanding that no mode of enforcement was intended. This alternative would conform to the history of the legislative division and disagreement out of which the policy emerged and with the character of the amendment that embodies the compromise policy. It conforms also to the curious silence of the amendment on the subject of enforcement, a silence which can only be taken to be deliberate on the part of the Legislature in view of the explicit and careful way in which this problem is handled elsewhere in the Welfare and Institutions Code with respect to responsible relatives. By this view, the Legislature intended the amendment merely as a declaration of principle to be put into operation administratively and to be further modified by the Legislature as experience proved necessary and pointed the direction.

(9) Finally, the inevitable question-who is a stepfather-must be answered. Is the definition the same under the Civil and the Welfare and Institutions Codes? Under the former, the status is acquired by marriage to the mother of the children. Civil Code Section 209, perpetuating the common law rule of no stepfather liability, does not use the word "stepfather" but speaks rather of "a husband" and "his wife's children by a former husband." According to Civil Code Section 55, to establish the marriage relation, "consent" and "solemnization" are both necessary. This being so, it is commonly said that there is no common law unarriage in California.

Welfare and Institutions Code Section 1508 seems to presuppose a valid Civil Code marriage. Liability for support is imposed "not withstanding the provisions" of Civil Code Section 209. The term "stepfather" is used but so is the phrase, "his wife's children"; and the limit of the stepfather's liability is declared to be "the wife's community property interest in his income." No such interest exists under the Civil Code in the absense of a valid marriage.

Suppose a man lives with a woman and her children; perhaps has one or two children by her; cares for the woman and children to the best of his ability and within his means; makes contributions, without court order, to 
the support of his own children who are residing with his former wife; represents to the children and community that he is married to the woman with whom he is living, though he and she know this is not so and there has been no solemnization; freely admits, in fact insists to the County Welfare Department that there was no marriage, that he has declined to marry because of stepfather liability and that if such liability is imposed, he will abandon the family; and suppose further that this relationship has continued for a period of three or four years.

Viewed in welfare and financial terms, this family situation and the needs of the children would not be different if the man and woman were duly married according to all the conditions set down in the Civil Code. Yet if stepfather hability is not imposed, the children are eligible for aid to needy children regardless of the man's income. A financial prenuim is consequently placed on the comnon law relationship, and inequity is sanctioned between common law and duly married stepfathers, and a line of distinction is drawn between the two which has little bearing upon the financial program of aid to needy children. On the other hand, to apply stepfather liability might well have a disintegrative tendency on otherwise stable unions with all that they may mean to the welfare and upbringing of the children. The deterrent effect of the stepfather policy on the remarriage of the mother and the reestablishment of two-parent homes for the children would thus be extended to deter the common law relationships encouraged by the stepfather policy; and especially to deter continuous and stable common law unions in favor of those that are temporary, fleeting and fly-by-night.

Confronted with the case above supposed and with these welfare and family considerations, the State Social Welfare Board applied stepfather liabihity. In effect, the Board thus lield that, while there are no common law husbands under the Civil Code, there are common law stepfathers under the Welfare and Institutions Code; and that, by illicit cohabitation with a man, the mother of children receiving aid to needy children acquires a comnuumity property interest in his income. ${ }^{92}$

\section{THE COURTS VIS A VIS TEE WELFARE DEPARTMENT}

Can a superior court judge, acting under the Civil Code in a suit duly brought to enforce the support obligation of a parent towards a minor child who is receiving public assistance on the ANC prograin determine that the items needed by the child for his support are more than, less than, or different from those specified in Welfare and Institutions Code Section 1511.5? If bound by that listing, is he free to define and interpret those items differently from the Welfare Department? Is he free to fix a higher, lower or

92 Minutes, State Social Welfare Board, Feb. 1954, pp.iii, 6. 
different standard of assistance than that fixed by the welfare department under the express direction of Welfare and Institutions Code Sections 1511.5 and 1560 (a) (b) ? Is he free independently to determine the amount for which the absent father or mother is liable if his or her ability to pay has been determined by the county welfare department under the rules issued by the state department? If no such administrative determination has been made, must the judge then either secure one before fixing the absent parent's liability or else himself fix that liability according to the tests and standards used by the welfare department? In determining the support obligation of an adult child of an OAS recipient, is the judge bound by the tables of maximum contributions prescribed in the Welfare and Institutions Code and by the standard of assistance established there and in the pursuant departmental rules? In short, does the Welfare and Institutions Code and the administrative arrangenent and discretion vested thereunder oust the judges of the administration and discretion exercised and exercisable by them under the Civil Code provisions? Suppose, as directed by the Welfare and Institutions Code, the district attorney, pursuant to notice from the welfare department seeks judicial enforcement action under Penal Code Section 270-can the judge then make a fresh determination of ability to pay, ignoring administrative findings and the commands of the Welfare and Institutions Code?

The answers to these questions plainly must be that, with respect to these matters, the judges have been removed from the class of administrators and placed in the class of reviewers of administrators, except to the limited extent that the Welfare and Institutions Code itself provides otherwise. The Legislature has created a whole new system of welfare law. It is embodied in and comprises six chapters and 248 sections of the Welfare and Institutions Code. It enconpasses numerous substantive provisions and procedural requirements. It designates and establishes a whole administrative hierarchy and supplementary administrative machinery. It invests the administration with specific duties, imposes upon it specific limitations, and otherwise authorizes and directs it to establish policies and issue rules and regulations circumscribed by fixed guides and standards. Over a period of a quarter of a century, the nature of this system has been a matter of constant and pressing concern to the Legislature both in its overall character and its particular features. In each and every session of the Legislature during that extended time, many, sonetimes scores, of bills have been introduced and enacted into law adding to the system, amending, repeating and unodifying. Probably on no single subject during that time has the Legislature bestowed a greater amount of attention.

Conceived and developed with all this care, elaboration and detail, devoted to specific and limited purposes, affecting specific and limited groups 
in the population, involving not only substantive provisions but a special administrative set-up as well, welfare law must be held to repeal and supercede conflicting provisions of family law. It replaces as well judicial administration. Family law is far more comprehensive and general. It reaches the ricli as well as the poor; those in the prime of life as well as children and aged; the sighted as well as the blind. Out of these comprehensive and general provisions of family law in the Civil and Penal Codes, the Welfare and Institutions Code has carved a segment. For the government of that segment, the Welfare and Institutions Code has to some extent drawn upon the provisions of the Civil and Penal Codes either by presupposing or by explicitly incorporating them. It has modified and contradicted many others. It has provided especially a distinct administrative process and personnel. For the courts now to perform the administrative function and, to that extent, to displace the administrative personnel, is to impair the integrity of the administrative process and the value of specialized administration. It is to defy not only the system created by the state but also the federal requirements that the administration or the supervision of the administration of the state plan be by "a single state agency" and that the plan be uniform and state-wide in character. ${ }^{93}$

Under the Welfare and Institutions Code, the courts are assigned a number of specific tasks in welfare administration. Beyond these, their function is one of overall review, a review which is stirred into being only by individuals who feel themselves aggrieved by administrative action already taken and after administrative remedies already exhausted; and which, when thus stirred into being is confined by the Welfare and Institutions Code to an investigation of questions of law, those of fact being finally determinable by the administrators. ${ }^{94}$

83 Soc. Sec. Act Title I, § 2(a) (1) (3); Title IV, § 402 (a) (1) (3); Title X, § 1002 (a)(1)(3). 94 CAI. WeIf. \& INST. CODE $\$ 104.2$. 